\title{
PLASMA CHEMISTRY DEPENDENT ECR ETCHING OF GaN
}

R. J. Shul, ${ }^{*}$ C. I. H. Ashby, ${ }^{*}$ D. J. Rieger, ${ }^{*}$ A. J. Howard, S. J. Pearton, ${ }^{* *}$ C. R. Abernathy," C. B. Vartuli, ${ }^{* *}$ P. A. Barnes, ${ }^{\circ}$ P. Davis, ${ }^{\circ}$ and R. Connatser ${ }^{\circ 0}$.

"Sandia National Laboratories, Albuquerque, NM 87185-0603

* University of Florida, Gainesville, FL 32611

- Auburn University, Auburn, AL 36849

o University of Alabama, Huntsville, AL 36849

\section{ABSTRACT}

REPRIMB

DEC 271995

Electron cyclotron resonance (ECR) etching of $\mathrm{GaN}$ in $\mathrm{Cl}_{2} / \mathrm{H}_{2} / \mathrm{Ar}, \mathrm{Cl}_{2} / \mathrm{SF} / \mathrm{Ar}, \mathrm{BCl}_{3} / \mathrm{H}_{2} / \mathrm{Ar}$ and $\mathrm{BCl}_{3} / \mathrm{SF}_{6} / \mathrm{Ar}$ plasmas is reported as a function of percent $\mathrm{H}_{2}$ and ${ }_{2}^{2} \mathrm{SF}_{6} . \mathrm{GaN}^{2}$ etch rates were found to be 2 to 3 times greater in $\mathrm{Cl}_{2} / \mathrm{H}_{2} / \mathrm{Ar}$ discharges than in $\mathrm{BCl}_{3} / \mathrm{H}_{2} / \mathrm{Ar}$ discharges independent of the $\mathrm{H}_{2}$ concentration. In both discharges, the etch rates decreased as the $\mathrm{H}_{2}$ concentration increased above $10 \%$. When $\mathrm{SF}_{6}$ was substituted for $\mathrm{H}_{2}$, the $\mathrm{GaN}$ etch rates in $\mathrm{BCl}_{3}$-based plasmas were greater than those for the $\mathrm{Cl}_{2}$-based discharges as the $\mathrm{SF}_{6}$ concentration increased. GaN etch rates were greater in $\mathrm{Cl}_{2} / \mathrm{H}_{2} / \mathrm{Ar}$ discharges as compared to $\mathrm{Cl}_{2} / \mathrm{SF}_{6} / \mathrm{Ar}$ discharges whereas the opposite trend was observed for $\mathrm{BCl}_{3}$-based discharges. Variations in surface morphology and near-surface stoichiometry due to plasma chemistries were also investigated using atomic force microscopy and Auger spectroscopy, respectively.

\section{INTRODUCTION}

Wide band-gap group-III nitrides continue to attract interest as blue and ultraviolet emitters and detectors, high temperature electronics, and passivation layers ${ }^{1-5}$. Recent advances in the growth of GaN films have resulted in device demonstrations of GaN light emitting diodes (LEDs) ${ }^{6.7}$ and metal semiconducting field effect transistors (MESFETs) ${ }^{5,8}$. Although progress has also been reported in dry patterning these materials, rapid development of material growth and advanced device structures including lasers and heterojunction bipolar transistors (HBTs) has increased the need for anisotropic, smooth, high-rate etching. A variety of plasma etch chemistries have been reported in a reactive ion etch (RIE) system using chlorine- ${ }^{10,11}$ and bromine- ${ }^{12}$ based plasma chemistries. Etch rates for GaN up to approximately $650 \AA / \mathrm{min}$ have been reported at dc biases of $-400 \mathrm{~V}$. Significantly higher etch rates have been reported in electron cyclotron resonance (ECR) etch systems where the plasma is confined by a magnetic field to provide a high density plasma at low pressure and low ion energies. Most ECR etching of $\mathrm{GaN}$ has been performed using $\mathrm{Cl}_{2} / \mathrm{H}_{2}-$ based plasmas. ${ }^{13-15}$ Highly anisotropic GaN etching was obtained at dc-biases ranging from -150 to $-250 \mathrm{~V}$ with etch rates exceeding $2800 \AA / \mathrm{min}$.

In this paper, we report ECR etching of $\mathrm{GaN}$ as a function of plasma chemistry using $\mathrm{Cl}_{2} / \mathrm{H} / 2 / \mathrm{Ar}, \mathrm{Cl}_{2} / \mathrm{SF} / \mathrm{Ar}, \mathrm{BCl}_{3} / \mathrm{H}_{2} / \mathrm{Ar}$, and $\mathrm{BCl}_{3} / \mathrm{SF} / \mathrm{Ar}$ plasmas. These discharge chemistries are expected to etch $\mathrm{GaN}$ due to the high volatility of the Ga-chlorides and the formation of volatile $\mathrm{NH}_{\mathrm{x}}$ or $\mathrm{NF}_{\mathrm{x}}$ etch products with the addition of $\mathrm{H}_{2}$ or $\mathrm{SF}_{6}$ to the plasma.

\section{EXPERIMENT}

The GaN films were grown using Metal Organic Molecular Beam Epitaxy (MO-MBE) on GaAs substrates in an Intevac Gen II system described previously. ${ }^{16}$ The group-III source was triethylgallium and the atomic nitrogen was derived from an ECR Wavemat source operating at 200 W forward power. The layers were single crystal with a high density of stacking faults and microtwins and were resistive as-grown.

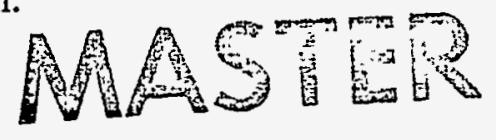


The GaN samples were patterned using a photoresist mask. The ECR plasma reactor used in this study was a load-locked Plasma-Therm SLR 770 etch system with an ECR source operating at $2.45 \mathrm{GHz}$. Energetic ion bombardment was provided by superimposing an rf-bias $(13.56 \mathrm{MHz})$ on the sample. Samples were mounted using vacuum grease on an anodized Al carrier that was clamped to the cathode and cooled with $\mathrm{He}$ gas. Etch gases were introduced through an annular ring into the chamber just below the quartz window. To minimize field divergence and to optimize plasma uniformity and ion density across the chamber, an external secondary collimating magnet was located on the same plane as the sample and a series of external permanent rare-earth magnets were located between the microwave cavity and the sample. ECR etch parameters held constant in this study were: $30^{\circ} \mathrm{C}$ electrode temperature, 1 mTorr total pressure, $30 \mathrm{sccm}$ total gas flow, 5 sccm of Ar, $850 \mathrm{~W}$ of applied microwave power, and $150 \mathrm{~W}$ rf-power with a corresponding dcbias of $-150 \pm 10 \mathrm{~V}$.

Etch rates were calculated from the depth of etched features measured with a Dektak stylus profilometer after removing the photoresist mask. Samples etched in the ECR were approximately $1 \mathrm{~cm}^{2}$ and depth measurements were taken at a minimum of three positions. Error bars for the etch rates were $\pm 10 \%$ across the sample. Limited sample supply precluded multiple runs at each condition. The gas phase chemistry of the plasma was studied using a quadrupole mass spectrometer (QMS). Surface morphology, anisotropy, and sidewall undercutting were evaluated with a scanning electron microscope (SEM). The root-mean-square (rms) surface roughness was quantified using a Digital Instruments Dimension 3000 atomic force microscope (AFM) system operating in tapping mode with Si tips. Auger electron spectroscopy (AES) was used to investigate the near-surface stoichiometry of $\mathrm{GaN}$ before etch and after exposure to several plasma conditions.

\section{RESULTS AND DISCUSSIONS}

The etch rate for $\mathrm{GaN}$ is plotted in Figure 1 as a function of percent hydrogen concentration for the $\mathrm{Cl}_{2} / \mathrm{H}_{2} / \mathrm{Ar}$ and $\mathrm{BCl}_{3} / \mathrm{H}_{2} / \mathrm{Ar}$ plasma discharges. The $\mathrm{GaN}$ etch rates were consistently greater

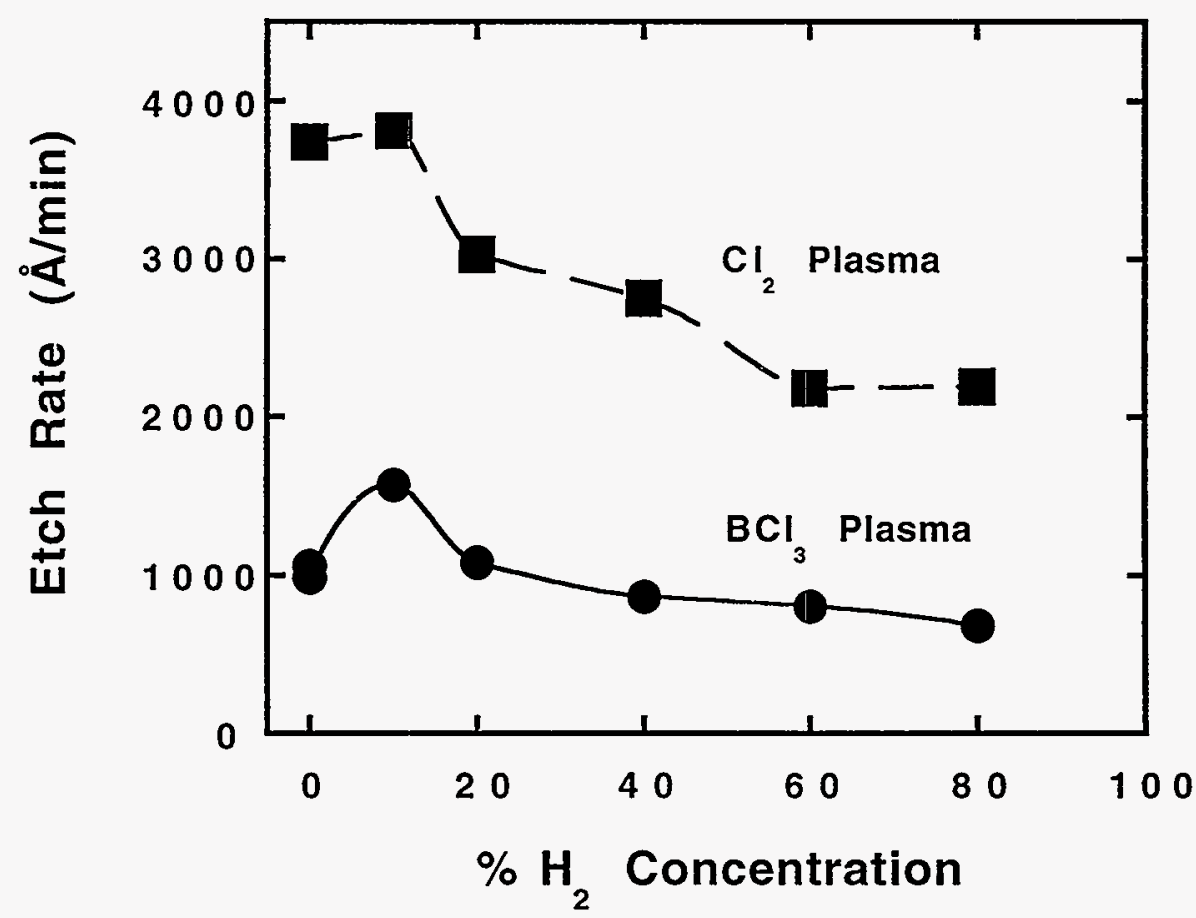

Figure 1. GaN etch rates as a function of $\% \mathrm{H}_{2}$ concentration for $\mathrm{Cl}_{2} / \mathrm{H}_{2} / \mathrm{Ar}$ and $\mathrm{BCl}_{3} / \mathrm{H}_{2} / \mathrm{Ar}$ plasmas. 
in the $\mathrm{Cl}_{2}$-based plasma as compared to $\mathrm{BCl}_{3}$ by a factor of 2 to 3 due to the higher concentration of active $\mathrm{Cl}$ species. The trends were similar for both plasmas as the $\mathrm{H}_{2}$ concentration was increased, however, the increase in etch rate at $10 \% \mathrm{H}_{2}$ was much more significant in the $\mathrm{BCl}_{3}$-plasma. The increase in etch rate observed at $10 \% \mathrm{H}_{2}$ concentration in $\mathrm{BCl}_{3}$ correlated with an increase in the reactive $\mathrm{Cl}$ concentration indicated by $\mathrm{m} / \mathrm{e}=35$ peak intensity. In the $\mathrm{Cl}_{2}$-based plasma, the $\mathrm{GaN}$ etch rate and $\mathrm{Cl}$ concentration remained relatively constant at $10 \% \mathrm{H}_{2}$. As the $\mathrm{H}_{2}$ concentration was increased further, the $\mathrm{Cl}$ concentration decreased and the $\mathrm{HCl}$ concentration increased as the $\mathrm{GaN}$ etch rates decreased in both plasmas, presumably due to the consumption of reactive $\mathrm{Cl}$ by hydrogen.

In Figure 2, $\mathrm{GaN}$ etch rates are shown for the $\mathrm{Cl}_{2} / \mathrm{SF}_{6} / \mathrm{Ar}$ and $\mathrm{BCl}_{3} / \mathrm{SF}_{6} / \mathrm{Ar}$ plasmas. With the substitution of $\mathrm{SF}_{6}$ for $\mathrm{H}_{2}$ in the $\mathrm{Cl}_{2}$-based plasma, the $\mathrm{GaN}$ etch rate was typically a factor of 2 lower. As the concentration of $\mathrm{SF}_{6}$ was increased the etch rate decreased up to $30 \% \mathrm{SF}_{6}$ followed by a slight increase at $40 \%$. As the $\% \mathrm{SF}_{6}$ was increased from 0 to 20 , the $\mathrm{Cl}$ concentration (m/e = 35) decreased but remained significant; $\mathrm{GaN}$ etching at $20 \% \mathrm{SF}_{6}$ might be expected based on the $\mathrm{Cl}$ concentration alone. However, formation of $\mathrm{SCl}\left(\mathrm{m} / \mathrm{e}=67\right.$ ) was observed at $20 \% \mathrm{SF}_{6}$. Consumption of the reactive $\mathrm{Cl}$ by $\mathrm{S}$ may be responsible for the reduced GaN etch rate. At 30 and $40 \% \mathrm{SF}_{6}$, the $\mathrm{Cl}$ concentration was greatly reduced and low $\mathrm{GaN}$ etch rates result. The opposite trend was observed for $\mathrm{BCl}_{3}$, where the $\mathrm{GaN}$ etch rates were significantly greater when $\mathrm{SF}_{6}$ was substituted for $\mathrm{H}_{2}$. The $\mathrm{GaN}$ etch rate increased up to $30 \% \mathrm{SF}_{6}$ and then decreased sharply at $40 \%$ $\mathrm{SF}_{6}$. The $\mathrm{Cl}$ concentration $(\mathrm{m} / \mathrm{e}=35)$ also increased as the $\mathrm{SF}_{6}$ increased to $30 \%$ and then decreased at $40 \%$. As with the $\mathrm{Cl}_{2}$-based plasma, there appeared to be a competitive reaction of sulfur with chlorine as the $\mathrm{SCl}$ concentration increased above $30 \% \mathrm{SF}_{6}$. Under most etch conditions, the trend of the $\mathrm{Cl}$ concentration correlated with the trends observed for the $\mathrm{GaN}$ etch rate. However, a higher concentration of $\mathrm{Cl}$ was observed at $40 \% \mathrm{SF}_{6}$ than $0 \% \mathrm{SF}_{6}$ while the $\mathrm{GaN}$ etch rate was greater at $0 \% \mathrm{SF}_{6}$. Studies are planned to elucidate the chemistry involved.

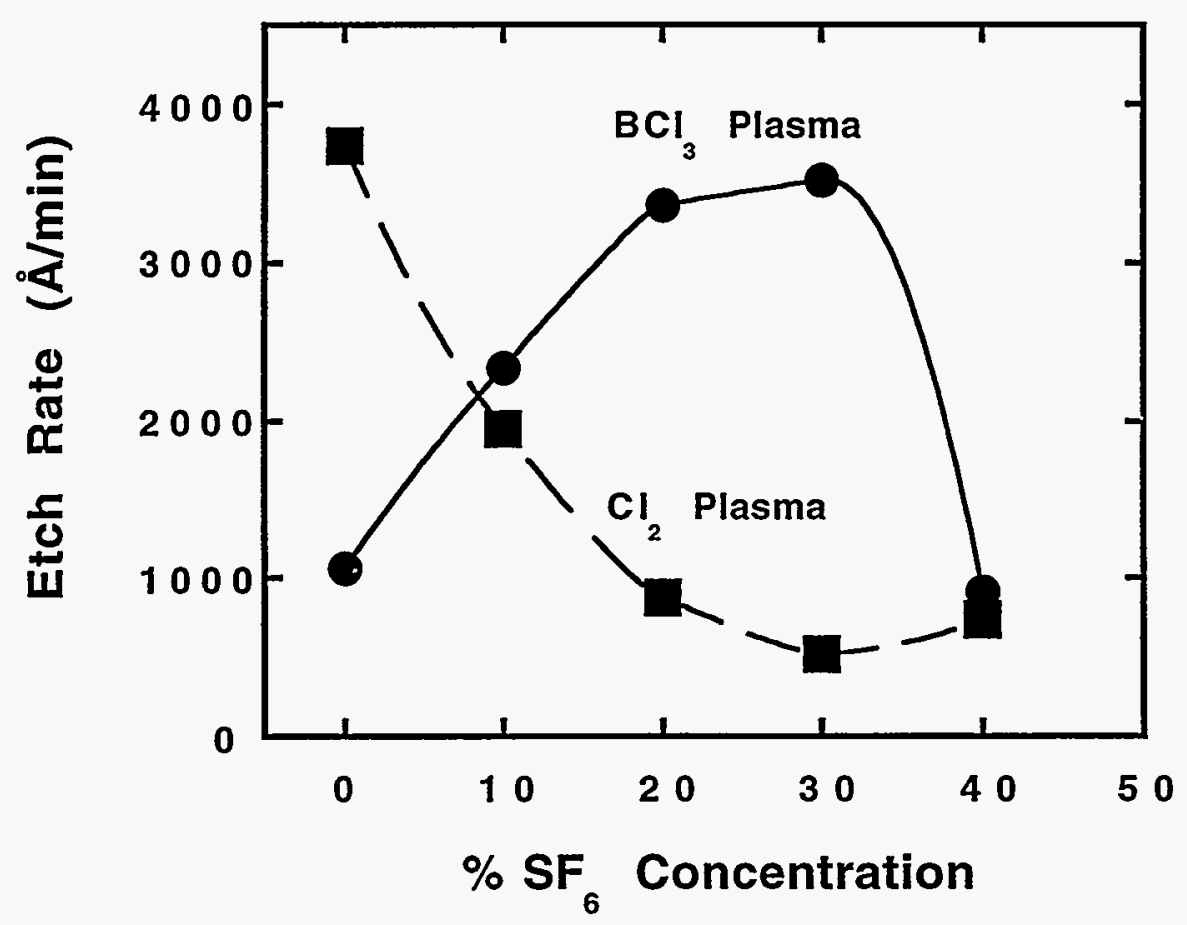

Figure 2. $\mathrm{GaN}$ etch rates as a function of $\% \mathrm{SF}_{6}$ concentration for $\mathrm{Cl}_{2} / \mathrm{SF}_{6} / \mathrm{Ar}$ and $\mathrm{BCl}_{3} / \mathrm{SF}_{6} / \mathrm{Ar}$ plasmas.

The root-mean-square (rms) roughness of the etched surfaces were quantified using AFM. In Figure 3 the rms roughness is plotted as a function of $\% \mathrm{H}_{2}$ for the $\mathrm{Cl}_{2}$-based and $\mathrm{BCl}_{3}$-based 
plasmas. The rms roughness for the as-grown $\mathrm{GaN}$ was $6.4 \pm 0.5 \mathrm{~nm}$. The rms roughness for GaN etched in $\mathrm{Cl}_{2} / \mathrm{H}_{2} / \mathrm{Ar}$ increased as the $\% \mathrm{H}_{2}$ increased from 0 to 10 and then decreased as the $\mathrm{H}_{2}$ concentration was increased further. The roughest surface was observed at $10 \% \mathrm{H}_{2}$ where the etch rate was greatest. In the $\mathrm{BCl}_{3} / \mathrm{H}_{2} / \mathrm{Ar}$ plasma the rms roughness increased slightly as the $\% \mathrm{H}_{2}$ increased, but remained relatively smooth. Pattern transfer into $\mathrm{GaN}$ was very smooth in $\mathrm{Cl}_{2} / \mathrm{SF}_{6} / \mathrm{Ar}$ and $\mathrm{BCl}_{3} / \mathrm{SF}_{6} / \mathrm{Ar}$ discharges with rms roughness ranging from 7.5 to $3.6 \mathrm{~nm}$.

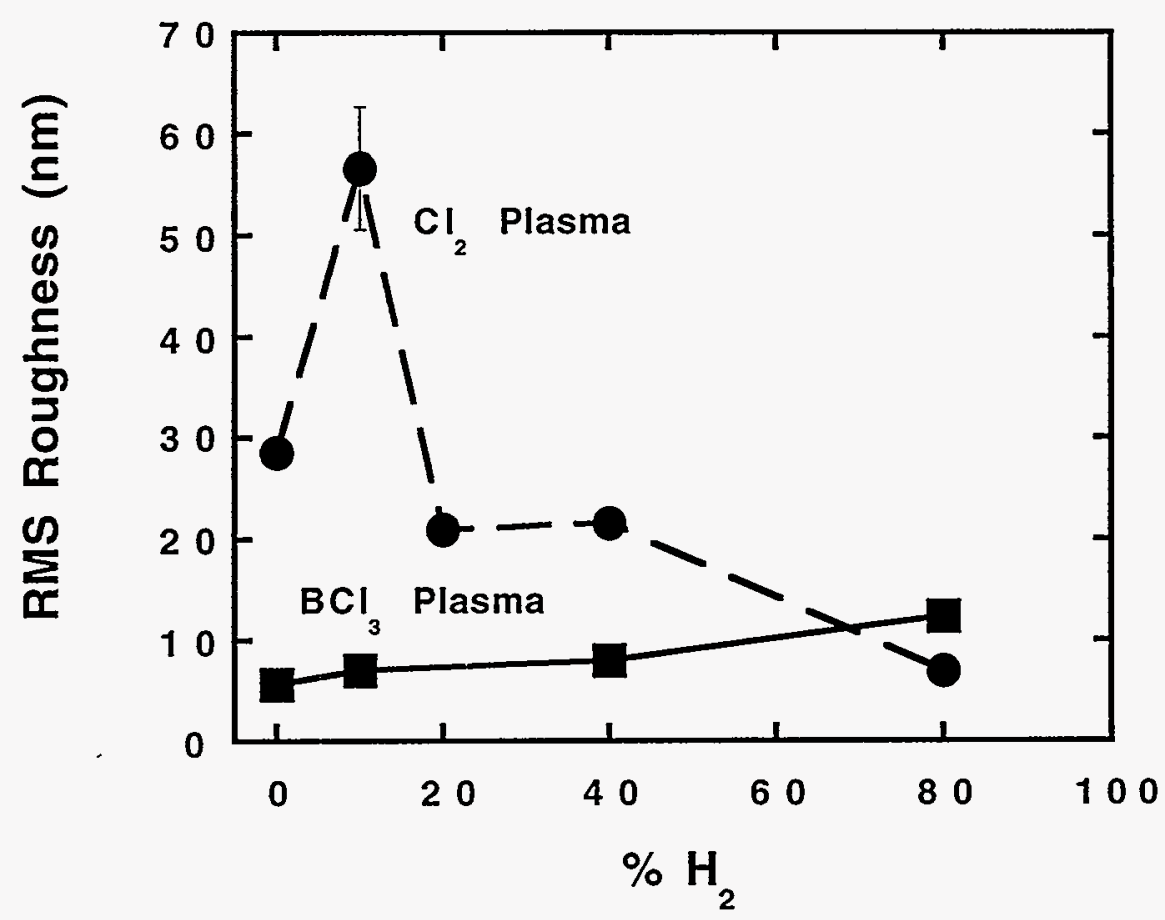

Figure 3. GaN rms roughness as a function of $\% \mathrm{H}_{2}$ concentration for $\mathrm{Cl}_{2} / \mathrm{H}_{2} / \mathrm{Ar}$ and $\mathrm{BCl}_{3} / \mathrm{H}_{2} / \mathrm{Ar}$ plasmas. The rms roughness for the as-grown $\mathrm{GaN}$ is $6.4 \pm 0.5 \mathrm{~nm}$.

The etch profiles showed a strong dependence on the discharge chemistry (Figure 4). The etched surface was quite rough (Figure $4 \mathrm{a}$ ) in the $\mathrm{Cl}_{2} / \mathrm{Ar}$ plasma possibly due to preferential removal of the $\mathrm{GaCl}_{x}$ etch products. The foot observed at the edge of the etched feature may be attributed to mask-edge erosion due to the aggressive attack of photoresist by reactive $\mathrm{Cl}$. As the $\mathrm{H}_{2}$ concentration was increased to $20 \%$ the etch became smooth and very anisotropic (Figure $4 \mathrm{~b}$ ).

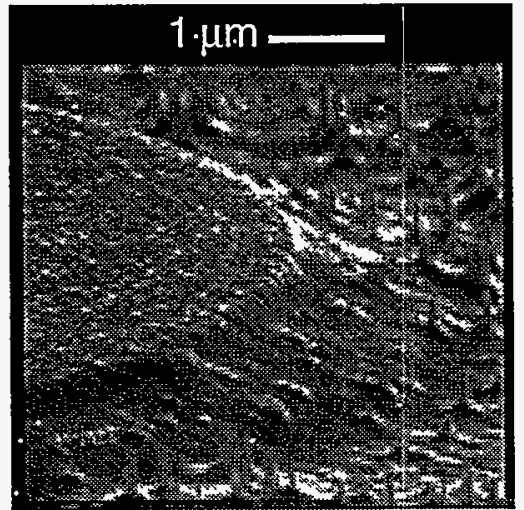

(a)

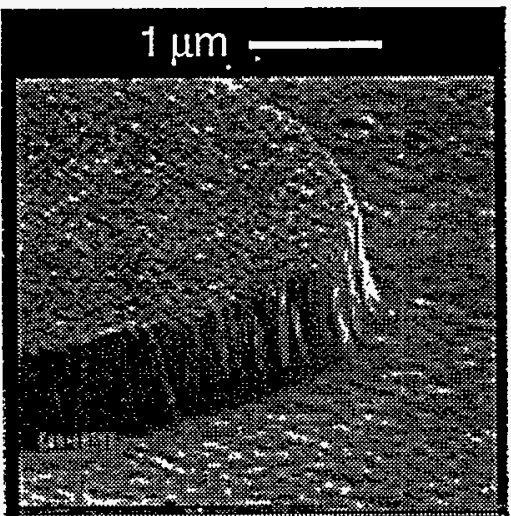

(b)

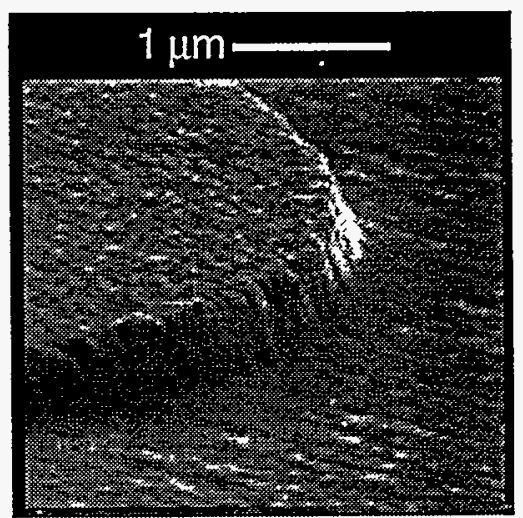

(c)

Figure 4. SEM micrographs of GaN samples ECR etched in (a) $\mathrm{Cl}_{2} / \mathrm{Ar}$ plasma, (b) $20 \% \mathrm{H}_{2}$ $\mathrm{Cl}_{2} / \mathrm{H}_{2} / \mathrm{Ar}$ plasma, and (c) $60 \% \mathrm{H}_{2} \mathrm{Cl}_{2} / \mathrm{H}_{2} / \mathrm{Ar}$ plasma. The photoresist mask has been removed. 
However, the SEM micrograph showed a lower density of surface roughness near the etched feature than AFM images scanned in open $10 \times 10 \mu \mathrm{m}$ areas. This may be attributed to a proximity effect of the etch where redeposition is worse in the open areas. It may also explain the smooth etch observed in Figure 4b where the rms roughness measured in the field was approximately 21 nm. At $60 \% \mathrm{H}_{2}$, the etch remained smooth and anisotropic with a slight foot at the base of the feature (Figure $4 \mathrm{c}$ ). The $\mathrm{GaN}$ etch profiles in $\mathrm{Cl}_{2} / \mathrm{SF}_{6}$ plasmas were anisotropic with relatively smooth sidewalls and etched surfaces. Etching $\mathrm{GaN}$ in $\mathrm{BCl}_{3} / \mathrm{H}_{2}$ or $\mathrm{BCl}_{3} / \mathrm{SF}_{6}$ resulted in anisotropic profiles with etched surface morphologies similar to the as-grown samples. The anisotropic profiles may have been improved in the $\mathrm{BCl}_{3}$-based plasmas due to the higher physical component of the etch mechanism as compared to $\mathrm{Cl}_{2}$-based plasmas.

Auger spectra for $\mathrm{GaN}$ samples etched under several different plasma conditions were taken to determine the near-surface stoichiometry. Prior to exposure of the GaN to the plasma, the Auger spectrum for the as-grown $\mathrm{GaN}$ showed a $\mathrm{Ga}: \mathrm{N}$ ratio of 1.5 with normal amounts of adventitious carbon and native oxide on the GaN surface. The Auger spectra showed vittually no $\mathrm{Ga}$ or $\mathrm{N}$ for $\mathrm{GaN}$ samples exposed to the $\mathrm{Cl}_{2} / \mathrm{Ar}$ plasma or the $80 \% \mathrm{H}_{2} \mathrm{Cl}_{2} / \mathrm{H}_{2} / \mathrm{Ar}$ plasma. This is not understood since the GaN was grown on GaAs and showed a minimum of $2500 \AA$ of $\mathrm{GaN}$ remaining after etch. Since the Auger spectra were near-surface and did not include any depth profiling, redeposition during etch may have prevented the observation of the $\mathrm{Ga}$ and $\mathrm{N}$ peaks. Further surface analysis are underway. For GaN samples etched in $\mathrm{Cl}_{2} / \mathrm{SF}_{6} / \mathrm{Ar}$, the $\mathrm{Ga}: \mathrm{N}$ ratio increased as the $\mathrm{SF}_{6}$ concentration increased implying that the $\mathrm{N}$ is effectively removed as $\mathrm{NF}_{\mathrm{x}}$. In the $\mathrm{BCl}_{3} / \mathrm{Ar}$ plasma the $\mathrm{Ga}: \mathrm{N}$ ratio increased from 1.5 for the as-grown sample to 1.9 following exposure to the plasma. This may be attributed to the preferential removal of the lighter $\mathrm{N}$ atoms due to the strong physical component of the etch mechanism in $\mathrm{BCl} 3$ plasmas. As the $\mathrm{H}_{2}$ or $\mathrm{SF}_{6}$ concentration was increased in the $\mathrm{BCl}_{3} / \mathrm{Ar}$ plasma, the $\mathrm{Ga}: \mathrm{N}$ ratio increased to 6.3 for $80 \% \mathrm{H}_{2}$ and 4.2 for $40 \% \mathrm{SF}_{6}$. Within experimental error, these trends imply that the GaN film is being depleted of $\mathrm{N}$ perhaps due to preferential chemical etching of the $\mathrm{N}$ atoms with the addition of $\mathrm{H}_{2}$ or $\mathrm{SF}_{6}$ to either $\mathrm{Cl}_{2}$ - or $\mathrm{BCl}_{3}$-based plasmas.

\section{CONCLUSIONS}

In summary, ECR etching of GaN is reported as a function plasma chemistry. GaN etch rates were greatest in $\mathrm{Cl}_{2} / \mathrm{Ar}$ and $\mathrm{Cl}_{2} / \mathrm{H}_{2} / \mathrm{Ar}$ at $10 \% \mathrm{H}_{2}$. Etch rates were a factor of 2 to 3 times higher in $\mathrm{Cl}_{2} / \mathrm{H}_{2}$ plasmas than $\mathrm{BCl}_{3} / \mathrm{H}_{2}$ plasmas due to higher concentrations of reactive $\mathrm{Cl}$. As the hydrogen concentration was increased above $10 \%$, the GaN etch rate decreased in both plasmas possibly due to consumption of the reactive $\mathrm{Cl}$ by hydrogen. When $\mathrm{SF}_{6}$ was substituted for $\mathrm{H}_{2}$, the $\mathrm{GaN}$ etch rates were greater in the $\mathrm{BCl}_{3}$-based plasma. The $\mathrm{GaN}$ etch rate increased as $\mathrm{SF}_{6}$ was added to the $\mathrm{BCl}_{3} / \mathrm{Ar}$ plasma up to $30 \%$ and then dropped sharply at $40 \% \mathrm{SF}_{6}$. This trend correlated qualitatively with the concentration of reactive $\mathrm{Cl}$. In general, $\mathrm{GaN}$ etch rates increased as the concentration of reactive $\mathrm{Cl}$ increased. Surface morphologies were evaluated and quantified using AFM. Very smooth pattern transfer was obtained for a wide range of plasma chemistries; however, the etched surface morphology was rougher in $\mathrm{Cl}_{2} / \mathrm{Ar}$ and $\mathrm{Cl}_{2} / \mathrm{H}_{2} / \mathrm{Ar}$ plasmas at low $\mathrm{H}_{2}$ concentrations. Etch profiles were more anisotropic with the addition of $\mathrm{H}_{2}$ or $\mathrm{SF}_{6}$ to $\mathrm{Cl}_{2}$. The etch profiles were typically more anisotropic with $\mathrm{BCl}_{3}$-based plasmas due to the physical nature of the etch while the etch rates were slower due to less reactive $\mathrm{Cl}$ present in the plasma. Using Auger spectroscopy, we have observed a general trend where the $\mathrm{Ga}: \mathrm{N}$ ratio increased as the concentration of $\mathrm{H}_{2}$ or $\mathrm{SF}_{6}$ increased implying a substantial chemical etch mechanism to remove $\mathrm{N}$ atoms from the GaN film.

\section{ACKNOWLEDGMENTS}

The authors would like to thank P. L. Glarborg, A. T. Ongstad, and L. Griego for their technical support. This work was performed at Sandia National Laboratories supported by the U.S. Department of Energy under contract \# DE-AC04-94AL85000. 


\section{REFERENCES}

1. S. Nakamura, T. Mukai, M. Senoh, and N. Iwasu, Jpn. J. Appl. Phys. 31, L139 (1992).

2. J. S. Foresi and T. D. Moustakas, Appl. Phys. Lett. 62, 2859 (1993).

3. S. Nakamura, T. Mukai, and M. Senoh, Appl. Phys. Lett., 64, 1687 (1994).

4. S. J. Pearton, C. R. Abernathy, P. Wisk, W. S. Hobson, and F. Ren, Appl. Phys. Lett. 63, 1143 (1993).

5. S. C. Binari, L. B. Rowland, W. Kruppa, G. Kelner, K. Doverspike, and D. K. Gaskill, Electron. Lett. 30, 1248 (1994).

6. S. Nakamura, M. Senoh, and T. Mukai, Jpn. J. Appl. Phys. 30, L1708 (1991).

7. I. Akasaki, H. Amano, M. Kito, and K. Hiramatsu, J. Lumin. 48/49, 666 (1991).

8. S. Nakamura, M. Senoh, and T. Mukai, Appl. Phys. Lett. 62, 2390 (1993).

9. M. A. Khan, J. N. Kuznia, A. R. Bhattarai, and D. T. Olson, Appl. Phys. Lett. 62, 1248 (1993).

10. I. Adesida, A. Mahajan, E. Andideh, M. A. Khan, D. T. Olsen, and J. N. Kuznia, Appl. Phys. Lett. 63, 2777 (1993).

11. M. E. Lin, Z. F. Fan, Z. Ma, L. H. Allen, and H. Morkoç, Appl. Phys. Lett. 64, 887 (1994).

12. A. T. Ping, I. Adesida, M. Asif Khan, and J. N. Kuznia, Electron. Lett. 30, 1895 (1994).

13. S. J. Pearton, C. R. Abernathy, and F. Ren, Appl. Phys. Lett. 64, 2294 (1994).

14. R. J. Shul, S. P. Kilcoyne, M. Hagerott Crawford, J. E. Parmeter, C. B. Vartuli, C. R. Abernathy, and S. J. Pearton, Appl. Phys. Lett, 66, 1761 (1995).

15. R. J. Shul, A. J. Howard, S. J. Pearton, C. R. Abernathy, C. B. Vartuli, P. A. Barnes, and M. J. Bozack, J. Vac. Sci. Technol. B. 13, 2016 (1995).

16. C. R. Abernathy, J. Vac. Sci. Technol. A 11, 869 (1993).

\section{DISCLAIMER}

This report was prepared as an account of work sponsored by an agency of the United States Government. Neither the United States Government nor any agency thereof, nor any of their employees, makes any warranty, express or implied, or assumes any legal liability or responsibility for the accuracy, completeness, or usefulness of any information, apparatus, product, or process disclosed, or represents that its use would not infringe privately owned rights. Reference herein to any specific commercial product, process, or service by trade name, trademark, manufacturer, or otherwise does not necessarily constitute or imply its endorsement, recommendation, or favoring by the United States Government or any agency thereof. The views and opinions of authors expressed herein do not necessarily state or reflect those of the United States Government or any agency thereof. 